\title{
An Effective Instructional Strategies Approach in Higher Education:
}

\author{
A Pilot Investigation \\ Ujjal Ahmod $^{1} \&$ Wenzheng Zhang ${ }^{1}$ \\ ${ }^{1}$ College of Management, Gansu Agricultural University, Lanzhou, China \\ Correspondence: Wenzheng Zhang, College of Management, Gansu Agricultural University, Lanzhou, 730070, China.
}

Received: January 21, 2021

Accepted: April 23, 2021

Online Published: April 26, 2021

doi:10.5430/ijhe.v10n5p68

URL: https://doi.org/10.5430/ijhe.v10n5p68

\begin{abstract}
Teaching is one of the major fundamentals in educational planning, which is the most important reason for educational management. The primary strategy of higher education should focus on student's self-determination activities, the institution's system a practical and experimental study, where students have a specific intention of studies and they can determine which areas would be studying comfortably. The paper aimed to visualize the usefulness of several potential research and teaching mode practices for instructing students at higher education level and to develop a puzzling concept. In the face of the significance of better teaching, the effect is far from the norm. This study has been used qualitative research methods and data (e.g. interview, online survey, groups focus, observation, and content) analyzed through a relevant field of literature. The results of the study emphasize and highlight the necessity for potential teaching strategies. Finally, teaching activities for the progress of applicable factors are discussed in the discussion and recommendation part.
\end{abstract}

Keywords: education planning, instructing, strategies, potential

\section{Introduction}

Education is an important endeavor to create intelligent progressive judgment comprehensively. Recently, all countries have always given priority to the education sector in their annual budgets and policies. Teaching and education are like both parts of paper money and the maximum conventional standard for proper teaching is the volume of student learning that happens. According to Regmi (2012) teaching is always figuring out an activity that proficient students to learn. Especially, some effective teaching ways include class lecturing, group discussions, laboratory experiments, field survey, and practical study. Moreover, concentration on this work in higher education is deliberate to be a principal one, so in their guidance, the learners must pay attention to the study and learning method; in addition to these two multiplications, teachers should go forward to acquire modern teaching methods (Bidabadi et al., 2016). Therefore, academic research is a crucial component of higher study and may play a significant role in the development of student's knowledge, their higher education experience, and comprehensive efficiency.

It is unthinkable to be a university teacher in many countries of the world based on passed the requite exam or academic achievements. Therefore, research is paramount, and having a Ph.D. degree with several publications is mandatory for getting a chance to teach at University Students. Granjeiro (2019) analyzed that an instructor develops knowledge from an information provider agent to being a mediator, challenger, and supervisor to a regular researcher with students. To be a professional teacher or become a future researcher need to be involved in evidence-based research as a role model (Diery et al., 2020). As a consequence, educators have to be critical readers of scientific and educational research analysis publications (Loughran, 2014). Their teaching should be based on the worth empirical record obtainable, and need to perceive that part of their professional conduct is to cooperate to the improvement and dissemination of research arisen skills (Livingston et al., 2009). In addition to meeting ideological standards, involvement in educational research further develops teacher-learners' private practice and knowledge, how their teacher trainees learn, and research on teacher education. Learning and teaching in a university setting are distinct from other kinds of higher education, because of its flat connection with research (Camacho et al., 2017).

The current study delivers an overview of highly applicable endeavors regarding research-based practice in higher education. Evidence-based practices have been introducing as a way to encourage teaching. In particular, to raise the conduct of standards in higher education instructing, it is important to understand the role of teachers and their approach to research-based practice. However, few scholars argue rational idea advising is effective only when it is 
integrated into the instructing of particular knowledge and skills stated by Behar-Horenstein \& Niu (2011). Others perception that major thinking knowledge is a general subset of skills that should be taught several. Based on previous literatures, teachers at all universities need to continue more potential study on how to educate their students in a significant way. The study of these objectives is following;

- To analyze the effective teaching way used by the teacher to teach higher graduate students.

- To provide accurate analytic knowledge of various teaching strategies as dynamic and paramount for university students.

- To give some recommendations for developing characteristics of instructing in the highlight of student's rational knowledge.

Fundamentally, this article has significant educational synthesis at university level instructing practice. Furthermore, the researchers follow this study as a contribution to boosting indicators involved in the improvement the future research in analogous settings. In the point out of the above, this study highlighted to help university teachers, future academic researchers, faculty members, the Ministry of Education, and develops instructor characteristics in higher education. Therefore, the study provides knowledge of the effective teaching methods that are most comprehensive in the systematic literature of university education as well as the possibility of forming future performance in teaching professionally.

The study completely following this framework;

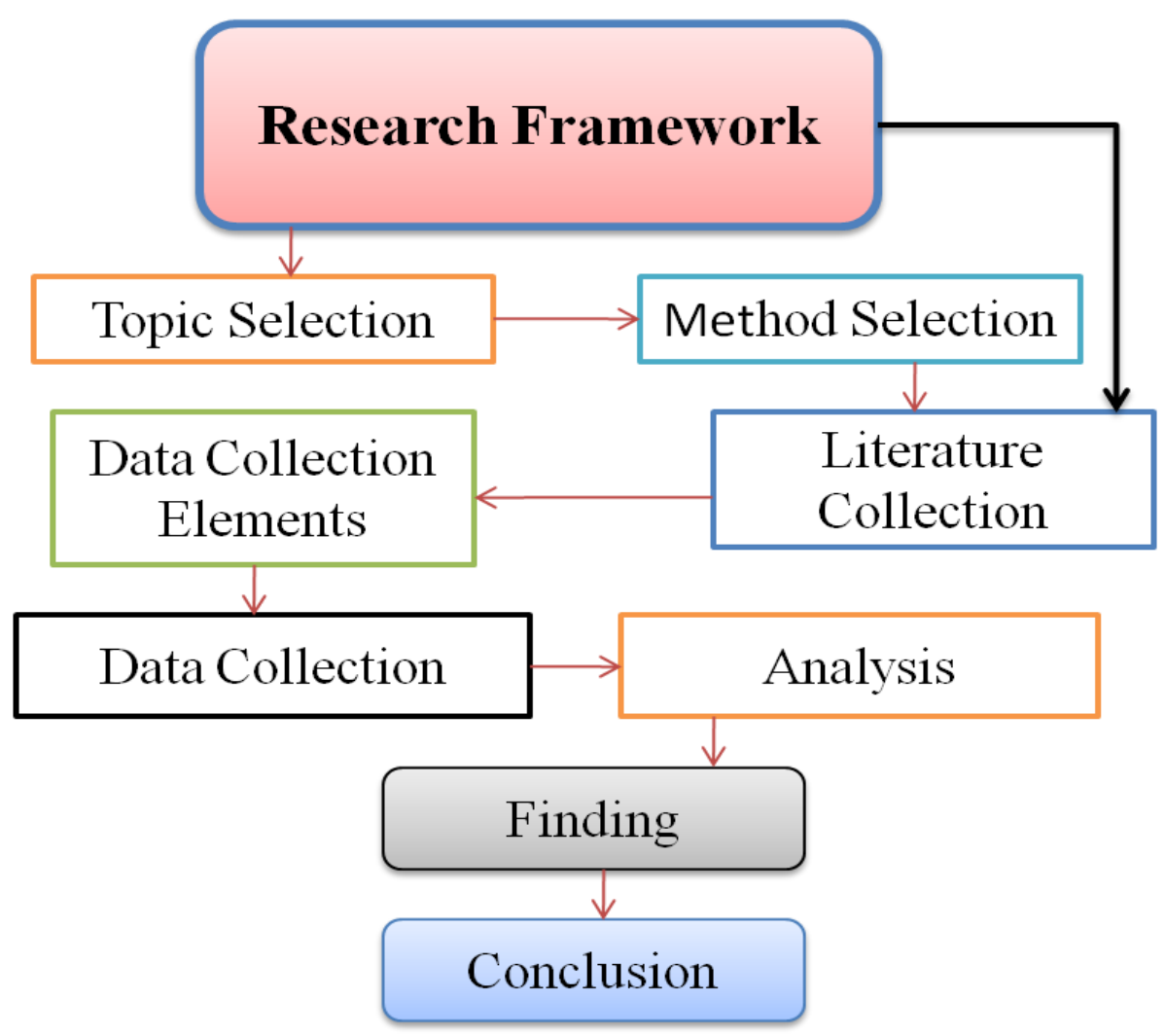

\section{Literature of Review}

Figure 1. Research framework and study flow

The key concept of the study, effective instructing and potential teachers that have been interpreted from various perspectives in the literature. Vries \& Beijaard (1999) emphasized that the proper teaching is also a remarkable contribution and it leads students to get the achievement. In addition, the researcher Berliner (1983) figures out the four key components of effective teaching: the attribute of instructing, considering learner's knowledge level, inspiration, and sufficient duration for learning. Moreover, according to Khandelwal (2009) the six principles of potential teaching system as follow in higher education include interest and discussion, care for student and respect knowledge, adequate assessment and answer, independence, perfect aims, and intellectual challenges, and learning 
from students. Therefore, the updated education should consider the student's independent activity, the University Self-learning Opportunities, and practical study, where students have the personal intention of deeds as well as can work comfortably (Yakovleva \& Yakovlevb, 2014).

This segment begins with a summary of research on the integration of research and teaching, debating for educational practice access that prioritizes the role of disciplined working groups in implements directions to integrating research into teaching.

\subsection{Effectiveness of Teaching (Theoretical and Experimental)}

First, the advent of higher education in the 1960s and beyond changed the perception of the role of universities. This raised questions about the behavior of the relevance between teaching and research. Materially, teaching was the main action of universities until the end of the nineteenth century founded by Peter \& Lawrence (1999). The observations most of the educators are prospective to be lively engage in both generations of modern study (Research) and flowing of knowledge (Teaching). According to Kalyani \& Rajasekaran (2018) effective teaching is more essential for the modern and upcoming education system to support learners achieve their fulfill goals.

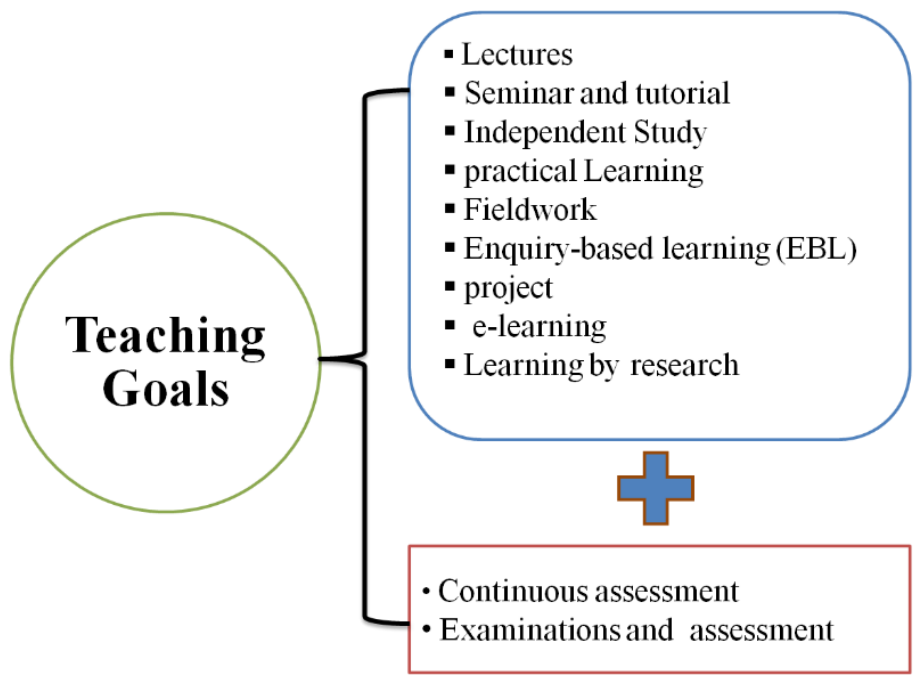

Figure 2. Theoretical teaching methods in higher education

It is believable, specifically in undergraduate instructing that teachers will regularly take part in lectures in the classroom. Lectures are extensively employed throughout the university to provide a lesson, concepts, and knowledge to the full class of students. A lecture is usually a presentation show that delivers the student a complete idea of a subject. Usually, the lecturer will indicate the students and ordinarily, no one will make a question until the end of the lecture, although in the end there is always get chance to ask a particular query. A seminar or tutorial engages many small groups of learners. Likewise, lessons are mostly conducted by a professor and may employ a presentation but the layout is usually not formal and enhances free speech about a certain subject. Studying independently does not mean that students will get a chance to study themselves. In this case, the teacher provides full support so that the student can acquire knowledge about the area of choice. Fieldwork may be a mandatory part of a few specific subjects. The Enquiry Based Learning access places emphasis on motivating students to conduct their personal line of inquiry through making indefinite question. The project will usually be in the final year, depend on the degree the student is studying. The teacher will usually tell how long will spend on the project, or the students will decide themselves. In some cases, the student has to give a completely formal presentation about the outcome of the project. Several subjects have may involve online material that part of the assessment of students' degree. Students have the opportunity to engage in research work even at undergraduate levels. These possibilities allow involvement in work that has a positive impact on the educational degree and future studies. Many lessons have a few forms of continuous student assessment. This means that at the end of the year or courses, the acquired of the task, project, and laboratory work are teachers taken into consideration when deciding to publish the results. Examinations may be the crucial approach of assessment students will encounter at University it helps them to develop skills (writing, analytical) that students necessary to improve.

The key motive of teachers is to develop new concepts and increase research proficiency for the advancement of knowledge (Prince et al., 2007). Researchers are primarily valued for what they discover and the problems make 
solutions, and for teachers what they capable their learners to find out and solve. An ideal teacher should be a skillful communicator, familiar with situations that encourage learning to establish them, and be apprehensible and empathetic. Kugel (1993) stated that the instructing skills of university professors as well as the learning skills of their students seem to be evolving. An effective teacher can only deliver powerful knowledge through the students in a different profession and always keeps remarkable contributions to the country or society. There are various circumstances contribute to this approach to higher education including preparing a student as a researcher. Instructors applying a variety of methods to simplify learning such as class lectures, live discussions, lab experiments, case studies, interactive practice activities, quizzes, and presentations (Murphy et al., 2018). These teaching ways are significant in the instructing and learning procedure, along with the acquisition of knowledge and boost the number of students' engagement.

Since the $19^{\text {th }}$ century, science teachers have considered that laboratory education is very important. Because it provides observational training, informs about the perceptions and application of elaborated and relevant data as well as arouses the curiosity of science background students.

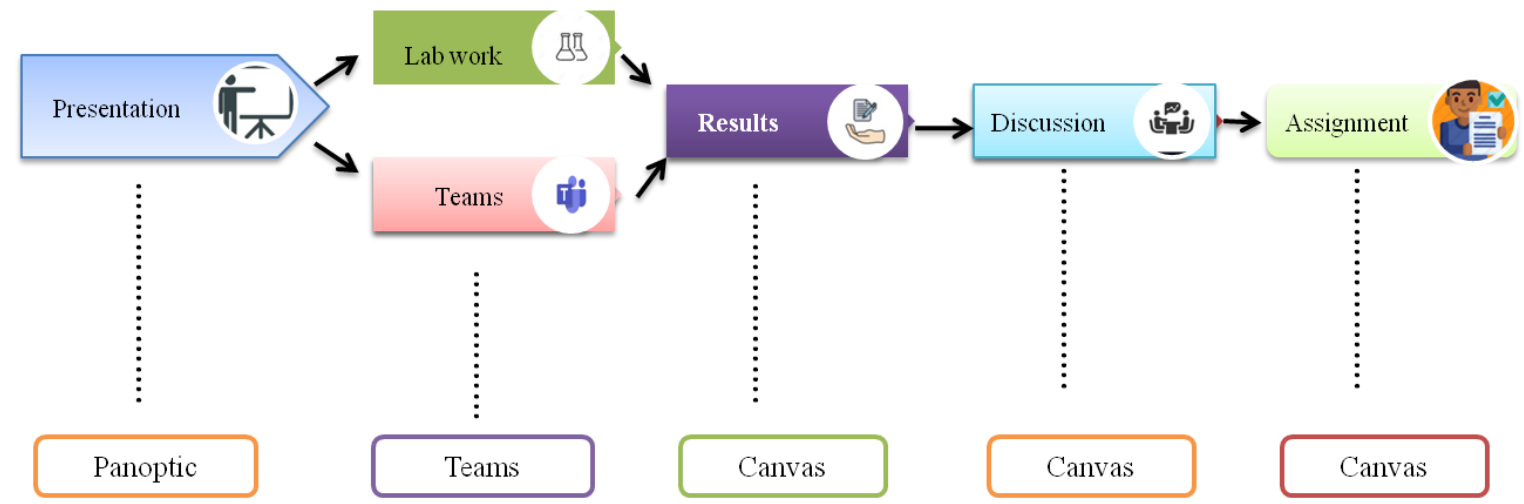

Figure 3. Approaches to laboratory study instruction

Lab-based Teaching in the higher education levels, Laboratories are no substitute for teaching and learning science. Teachers and laboratories deliver students a suitable environment to experiment, learning to operate the machine, discussion, and accomplish research work. The concept of laboratory learning takes that primary experience in observing and manipulating elements of science is auspicious to other ways of comprehension and intellectual development. Laboratory training is often used to improve the efficiency needed for modern research. However, in case a simple mistake can be more expensive or dangerous for new students learns to experiment, necessary to learn to use more advanced equipment (like the character of a lab environment due to research) and analyze the data (Kirschner \& Meester, 1988). According to the teacher's makes schedule, undergraduate students may even participate in extensive research practice the laboratory (Adams, 2009). There is a huge disparity in the learning strategies of students from one category of laboratory activity to another, which is revealed through appropriate instructing by the teacher analyzed by Hofstein \& Lunetta (1982).

Non-laboratory experiments (Dry labs) and particularly multimedia base practical study is supposed to be applying for fully not similar causes. They are properly used to assist students in acquiring specific cognitive skills (such as analysis, implication, and evaluation) required to practice science and conduct scientific research (Huisman \& Kirschner, 2007). Use software such as Statistics, Applied mathematics, ICT, Robotic science, and physics to able students to carry out scientific studies and experiment by computer. Therefore, that teacher can effectively teach and give opportunities for students to learn themselves indicated by Muhtasib (2019).

According to Suarman (2015) effective instructing and better teaching often refers to the presence of exact teaching process, ability to meet learning requirements and prospective in teaching, favorable physical opportunities, friendly colleague, and outstanding official services. Perumal (2009) mentioned there is a growing interest in research at the university to integrate spiritual teaching skills and the motivation of teaching students and teaching methods to build oneself apart.

\subsection{The Relationship between Teaching and Research}

The relatively free relationship between teaching and research compared to other institutions of education conducted to maintain a university's standards (Verburgh et al., 2007). Institutions of higher education learning usually engage in research, instructing, and employment. Teaching can create redouble student's knowledge, research conducts to the 
improvement of a new concept, and works cooperatively with the growth of university faculty members, non-academic or professional. The debate focuses specifically on teaching and research and raises concerns about the proper way to incorporate the higher education system in the United States, with separate department works, institutions, and the entire loose lee for maximum teaching appropriateness and research productivity. Brew (2006) founded all research and teaching activities that take space in a scholarly topic depend on conventional dishearten on the behavior of knowledge.

Analysts who understand that teaching and research improve each other dispute that potential researchers are known and involving teachers and encourage faculty creativity with perseverance for research. Economic theory suggests that teaching and research are complementary. Since they use the same resources, opportunities, and many staff, teaching and researching together is more efficient than producing them individually. Similarly, implement both teaching and purpose of research at the same time, individual faculties can develop their proficiency and productivity if sometimes involve in performances.

Ultimately, research is understood as a scientifically or empirical investigation into the disciplinary content of university communities. However, research is about finding the answer to a question, and purpose may consider the exact ways to teach in a particular discipline (Neumann, 1992). This is informed as "Scholarship of Teaching and Learning" and it always researchers the impact of someone's pedagogy on pupils studying results (Gilmore et al., 2015). Instructing should be interrelated in research, and the University Professors mainly teach properly what they gathered knowledge in the particular field analyzed by Bemowski (1991). The relationship between both an extensively captures through academics to be a crucial segment of confirming efficiency.

The relationship between research and teaching is as productive as concerning. Therefore, an effective teacher may also discuss through open any research paper in the classroom like a course as usual, which at the same time helps the students to review the research-based article and deliver much crucial knowledge on few subtle areas (writing style, method, and whole format).

\subsection{Integrating Research into Teaching Higher Education}

The rationale for integrating teaching and research is compatible with the opinion that faculties and universities have to improve the situational and technical perplexity of treating faculty as professionals- highly skilled, supple, and complex employees who enable to independently deal with and manage related tasks in a creative method. It has been a debate that the integration of research into instructing is critical in introducing the expected learning to higher study (Marsh \& Hattie, 2002). It is another argued that the integration of research and teaching is not self-acting, however, it important to be consciously enhanced to establish it into student learning, especially at the university level (Brew, 2010). In order to integrate research into education, various strategies have been adopted to focus on academics. Studies have shown how academics define undergraduate research and how research influences reliance on teaching and learning (Wilson et al., 2012). In higher education levels, students start to consume a rising proportion of their valuable time for researching. Typically, university students study one or more semesters in labs or practically, although the kinds of activity and type of supervising vary considerably (Harvey et al., 2017).

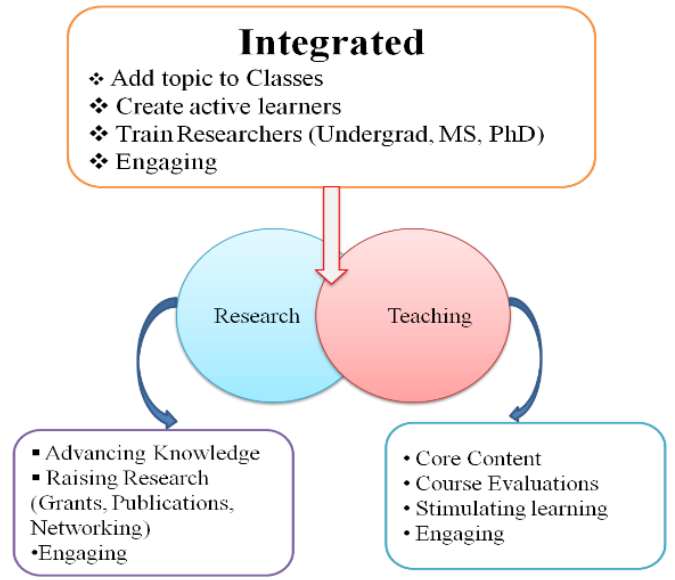

Figure 4. Integration Scenarios between Research and Teaching

\subsection{The Role of Literacy in Higher Education}

In current times, the again structuring of the university curriculum to confirm a mobilized approach to the 
improvement of literacy for learners has been involved as a vital goal for higher secondary institutions, and increasingly featured in the university emission statements and instructing certificates for the twenty-first century (McGuinness, 2006). Unanimous literacy efficiency is asked for in all sectors, including science and technology, a fact that is not entirely lost on occupational bodies (Fullerton \& Leckie, 1999). Bruce (2013) stated literacy for Higher education discipline is essential for both teachers and students. As well as ensuring the objectives of education people are prepared and inspired to learn from the extent of educational institutions around them. The higher education program includes educational media: tutorial; Practical studies for specific subjects; Studies and independent research and intensive training sessions (Sacchanand, 2002). The development of such faculty members can be happened away range Strategies for improving the quality of instructing and learning have already taken a position in several Australian universities. Disciplinary experts are needed to conduct a discourse clearly outside their discussion community and this is where academic literacy practitioners play a significant role (Jacobs, 2007). The implications of this part are the need to generate a place for higher education to collaborate with literacy practitioners and lecturers so that literacy instructing can be studded in the discourse of the study.

\subsection{Information Literacy Teaching in Higher Education}

In higher education, there are four kinds of ways to current literacy teaching. Intra-curriculum: Information literacy is studded into learning results, education activities, or assessment of a major subject or an instructing program, usually through collaborative partnerships between faculty and library member. Li (2006) reconded that the librarians in the university libraries have a long history of the curriculum is differently described as library teaching, bibliographic advising, or reader learning, or often as Information efficiency or literacy activities.

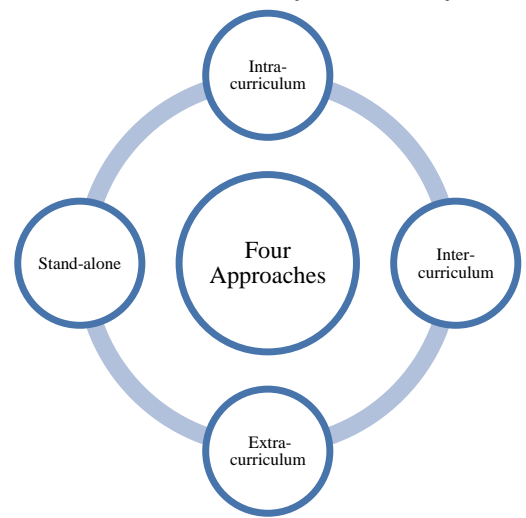

Figure 5. Major literacy types of teaching in higher education

Inter-curriculum: Data literacy is offered as gather in Sessions (s) for any academic subject or discipline through the library with or in consultation with an especial faculty member. Usually, attendance is a necessary Course or program.

Extra-curriculum: the Literacy Library away of the curriculum offers information, and presence is willful. Academic librarians have planned and founded library programs to assist learners to use library curricula effectively.

Stand-alone: the individual literacy subject is either a credit or non-major course taught as a selection lesson, or as a mandatory program as part of a common education program provided by a faculty or university.

Therefore, this suggests the integration of data literacy structure Curriculum is the potential approach to provide information literacy knowledge. The pick of insooth instructing and learning deeds depends on a variety of topics, such as curriculum goals; specific teaching methods of the university, student-learning techniques, and nature Curriculum content (Jaffer et al., 2007).

\section{Method}

\subsection{Research Design}

This paper exactly employs research design qualitative research based. The framework is effective for this research reason it delivers the participants to explore personal sense concerting on factors that can develop the attribute of instructing in their perceptions. The participant chooses the willingness to contribute to the study. The online survey has been directed as sample collection from different public and private institutions, and all of them geographically situated Asia and Europe. Moreover, workable sampling system has been used to choose the individual teacher from different study field. Each of respondents connected in live video interview holds duration approximately 25 to 30 minutes, and only few of them response through the email also face-to-face interview. The main participants in the sampling structure of university professors (based on research, supervisor, regular teacher), and higher studies 
students. The majority of the participants (Professors) had more than ten years of teaching (Laboratory, practical, and classroom) experience. This especial online survey was used from May to November 2020. All of them identified individually and after taken the appointments schedule explained the purpose of the research. Latterly, they briefed compliance for the interview to perform.

The study research methodology is following;

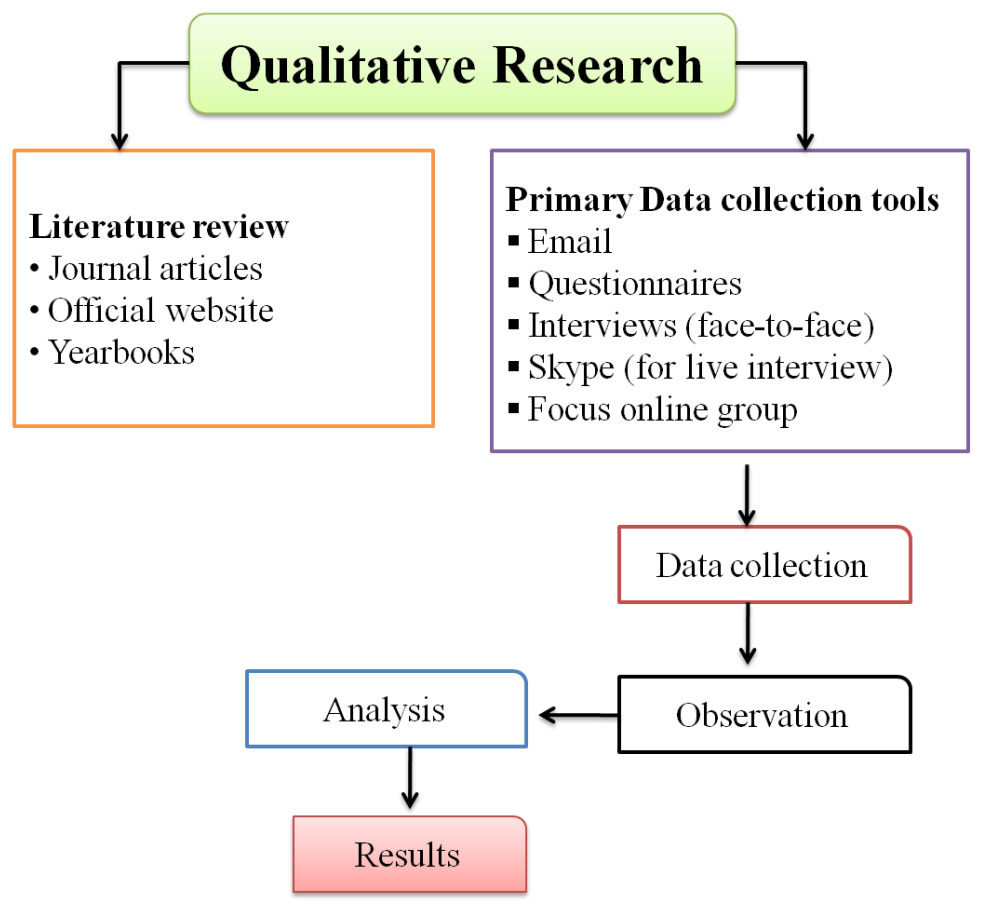

Figure 6. Full Research Method approaching diagram

\subsection{Data Collection Procedure and Tools}

The study conducted both primary and secondary sources. The primary data accumulated carrying semi-structured in profound interviews online (email, and separate virtual interviews by Skype), and during interviews with simple content such as "Please briefly describe your experiences an effective teaching". In addition, the individual interview's intention to figure out the basics of information like age, teaching fields, experience duration, gender, and others questions approaching graduate students teaching development strategy for considering the aims of the research. The interviews were conducted in privacy maintain with a selected suitable time. During connected the interview session with professors, we were well prepared a semi-structured questionnaires and arranged formatting of 150 highly experienced teachers in different instructing areas. Although, we were only selected total response based on email, face-to-face and Skype interview appropriately completed 123 samples, others 27 could not finalize because of incomplete information and not responded. Table 1 show that the responds from professor in various teaching fields.

Table 1. The characteristics of participants (Professor)

\begin{tabular}{lccc}
\hline \multicolumn{1}{c}{ Teaching fields } & Working duration & Age (Years) & Gender \\
\hline Economics & 26 & 62 & Male \\
Agriculture & 17 & 51 & Male \\
Biology & 14 & 49 & Female \\
Chemistry & 22 & 58 & Female \\
Civil Engineering & 15 & 47 & Male \\
Sociology & 18 & 52 & Female \\
Physics & 11 & 46 & Male \\
Linguistic & 13 & 42 & Female \\
Statistics & 16 & 49 & Female
\end{tabular}

Furthermore, another procedure of data collection was a questionnaire structured posted online in several university 
student groups and got 113 students response. The purpose of this questionnaire was to ask the university students what kind of teaching strategy expecting from the teacher's and giving priority to types of teaching they feel suitable being in the classroom and for practical learning. A total number of 236 responders (students and teachers) have been participated in the research by accomplishment of primary data collection procedure. The secondary data are collected from most of the journal articles, official publications, and online database to concern of the relevant studies (Sikder et al., 2020). Primary data were collected following qualitative methods, and secondary data were collected by observation.

\subsection{Data Analysis}

The both primary and secondary data collected from the relevant field of the study. Specially, the qualitative data was analyzed by the SPSS (version 10), and calculated to get the exact frequency. The secondary data were analyzed by Microsoft excel (2010 version) and used to draw the numbers of figures. Questionnaires and literature-based data have been measured calculating percentage formula that useable in the study.

$$
\text { Relative frequency as a percentages }(\%)=\frac{\text { Frequency score }}{\text { Total score }} \times 100
$$

Finally, measuring each of responder's data and then applied to calculate for getting the results.

\section{Results}

Details of the statements findings from the questionnaire data mention that according to the teachers and students respondents. There are following total six characteristics (8 Personality, 4 Efficiency) were most vital to describe effective instructing: are makes classes interesting; appropriate teaching strategy; respects students; friendly behaving to students; Understand (students thinking and feeling); Good senses of humor; Approachable or available; Cares about students' learning; Knows subject areas; Develops innovative activities; Relates out a theory to the relevant lesson; Develops learners proficiency.

Table 2. Effective instructors Characteristics (Personality and Efficiency) extracted questions and rank-ordered

\begin{tabular}{lcccc}
\hline \multicolumn{1}{c}{ Statements } & Rank & Instructor & Students & Sum \\
\hline Makes class interesting/fun & 1 & 25 & 25 & 50 \\
Appropriate teaching strategy & 5 & 9 & 21 & 30 \\
Respects students & 9 & 10 & 4 & 14 \\
Friendly behaving to students & 2 & 12 & 26 & 38 \\
Knows subject areas & 3 & 20 & 7 & 27 \\
Understand (students thinking and feeling) & 10.5 & 10 & 3 & 13 \\
Develops innovative activities & 21.5 & 2 & 2 & 4 \\
Good senses of humor & 15.5 & 2 & 5 & 7 \\
Relates out theory to relevant lesson & 17.5 & 6 & 5 & 11 \\
Develops learners proficiency & 21 & 2 & 2 & 4 \\
Approachable or available & 20 & 1 & 4 & 5 \\
Cares about students' learning & 4 & 24 & 9 & 25 \\
& & & Total Sum & 236 \\
\hline
\end{tabular}

Note: In table, italicized text mentions Personality factors; normal text indicates Efficiency factors.

Efficiency $\quad 46 \quad 19.50 \%$

Personality $190 \quad 80.50 \%$

Sum $236 \quad 100 \%$

Table 2 indicates that the "Make classes interesting or fun" most frequently responded trait, providing further support as to the importance of this result. An effective teacher should succeed in awakening the love of regular knowledge. These are the words written by a professor while answering the open question of the survey sample. The first highest rated efficiency characteristic responded to "Really knows subject areas" highly considered instructors than students. The second highest ranged personality characteristic of quality instructing to arise from this study was "Friendly 
behaving of students", lowest rated "Develops innovative activities" was student-teachers responded equally in the same factors according to survey information. Another category "Appropriate teaching strategy" (personality characteristics factors) responded with more concern for the instructor.

Analysis of the results suggests that teacher active participation of students and the use of an appropriate method, which is always explained by researchers in higher education. The most frequently responded factors are accepting knowledge; Encouragement, reciprocity and cooperation, learning techniques, Quick response, and punctuality in the classroom every day.

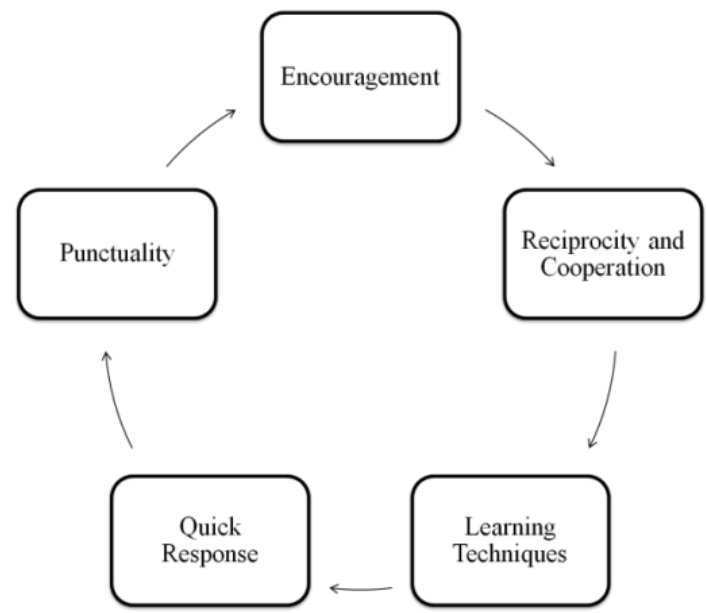

Figure 7. Teaching methods for good practice in higher education

The "reciprocity and cooperation with students" consider the obvious relationship, and it goes far beyond a respectful relationship between student and teacher. During teaching, when the teacher is clear-pointed and with a special guideline of the whole lesson, emphasizing the important and new terms that help the learners gain better insight and create more interest in the subject and the lesson.

In the next section, encouragement refers to providing potential support, confidence, or enthusiasm to students. It does not imply recognition of differences and if practiced properly it can inspire weak learners or help talented students to explore their knowledge. Encouragement all educators attach importance to stimulating the improvement of intellectual or subject-based efficiency, interest, and emphasizing the contribution of students.

Few educators point to the view "Quick response" indicates the attitude of a teacher that is appropriate in all categories of students. This means treating students to get understanding as much as early, and it would more helpful based on mental concentration. Quality instructing is the activity of engaging with students in a well-framed and certain learning zone.

A small number of teachers pay more attention to the rules of the "Learning Technique" in order to provide effective teaching. They, in particular, have given more prominence to practical, Laboratory experiments, and scientific approaches. The key cause of this question in this article is that teaching behavior has a huge impact on students' are learning (Ali et al., 2009).

Being punctual is an essential component of character in higher education. Describing the keynote and motive of punctuality is one matter, but engaging learners in the teaching procedure may undoubtedly help keep it stick. On the other hand, Punctuality is a crucial characteristic for all students to learn. These activities are structure to encourage students to be actively involved in this proficiency improvement process.

Table 3. Five Statements to describe the most effective university teachers positively in percentages

\begin{tabular}{lc}
\hline \multicolumn{1}{c}{ Statement Items } & Percentages \\
\hline Show worthy knowledge on specific areas & $98 \%$ \\
Add group activities during lesson & $96 \%$ \\
Encourage discussion & $95 \%$ \\
Easily accessible & $92 \%$ \\
Start lesson on time & $91 \%$ \\
\hline
\end{tabular}


The first item mentions (Table 3) that $98 \%$ of respondents strongly agreed a university instructor has to show brilliant knowledge about their particular subject and the $96 \%$ responses agree on focus group activities during the session that excellent strategy an essential quality of ideal university teacher. The group activities level of stable open conversation about raising a question, giving advice, and justifying speech. Being a group discussion in both theoretical and classroom, not science. These differences continue to grow over time. Moreover, these situations more often persist in group activities (Blatchford et al., 1995). In addition, 95\% responder mentions that the encouragement of discussion with students definitely provides deep thinking, when another approach 'research encourages students to have to gain a comprehensive idea. For an encouraging discussion to be effective, students have to actively listen to their peers, take an easy opposition point of view, and understand the value of broad-minded attitudes. They also can recognize the importance of concentrating and expressing themselves clearly. Nevertheless, this study suggests that and an easily accessible $92 \%$ of responders highly agree such as it is a significant part for the during higher education or university students. It students can be easily switched if the study examples are irrelevant to their own understanding. Furthermore, $91 \%$ are agreeing to the teacher should start lessons on time it helps to make students attentive and displays extra qualities towards the teacher.

\section{Discussion}

The results of this study confirm that improving the quality of teaching methods will increase the level of relative satisfaction among university teachers. It has been observing that there is a significantly different realization of the importance of teaching methods and research for higher education related to curriculum, lecturer motivation, teaching planning, and teacher behavior-based satisfaction. It may be concluding those students 'perceptions about the quality of instructors learning and research study certainly has a definite effect on their gratification. Many students expressed their self-confidence in improving their cognitive view through open discussion. During the teacher's discussions, students agreed on their capability to destination research ideas and widen their potential knowledge (Abdulbaki et al., 2018). Yet few give very little assurance about whether they are able to accumulate detailed opinions or liken their concepts with others.

A Plethora of evidence recommends that involving university students in research studies develops student enrollment, retention, and may seduce learners to postgraduate research careers. Several findings have mentioned that students benefited more from integrating research into their classroom when given the opportunity to develop their research skills, and participating in their activities (Obwegeser \& Papadopoulos, 2016). The above focus in this which method of research and teaching can be integrated is an interesting subject of discussion among educators, especially since each accomplishment of the between research and teaching ties is prospective to provide a variety of learning opportunities for students. Few university students believe that the research certainly provides deeper realization, relevance, and meaning to the particular subject, while another perceived research encourages students to have knowledge of a broader area (Allan et al., 2009). Students' priorities verbal explanations to those teachers or "almost translate into a way they can get," which is worth them to post "effective teachers" mentioned by West \& Bloxham (2007).

In higher education, especially at the graduate level, a massive range of instructing approaches is use than conventional discourse. In addition, learners may decide and study courses that particularly and apparently provide several methods of teaching and evaluation. In fact, students have strong priorities for and in opposition to specific learning methods that match their humor, skills, and experience (Chamorro-Premuzic et al., 2007).

The tasks of the experiments are characterized by many advantages beyond theoretical experience and practical ideas, as practical skills allow the student to succeed in all senses, capabilities, inspirations, and demonstrates studying efficiency. In the area of science education and teaching, professors agreed that applied study essentials students to attain data, and skills with form scientific aptitudes that make the procedure of teaching science effective. Teachers who are effective researchers are usually to maintain professional status and have knowledge of international quality teaching. According to Marsh \& Hattie (2002) since textbooks may not be present in many older and fast-growing regions, research lectures may be the latest medium for the appropriate teaching of higher education students.

Literacy teaching forms the foundation of the customary learning setting, where the educator executes the authority in the classroom and the students as instructed by the teacher. Recently, in the world where information explodes, students have to improve analytical realizing with extended learning efficiency to be able to grow and data evaluation, and students have to study how to learn. In addition, it is crucial to inflict literacy among teacher education sectors at the opening of the instructor learning stage. The outcomes of this education provide a framework for students to learn visual literacy for faculty, appraiser, and other educators (Hattwig et al., 2013).

Our attempt is therefore that all university students will undertake research as part of their degree at imperial, under 
the supervision of an active researcher.

\section{Conclusion and Recommandations}

Based on the results and discussions of the above study, it can be concluded that there is a significant similarity between teacher and student perceptions in specific fields. In this context, the development of innovative activities and learners' proficiency considers students and instructors both equally. Besides, student encouragement refers to providing potential support to an effective approach for the teacher. On the other hand, a university teacher or professor has to prove extraordinary knowledge about their exacting subject of areas. Furthermore, it has been observed that there is an extensively different insight of the crucial of teaching methods and research for higher education concerning curriculum, lecturer motivation, teaching planning, and teacher behavior-based fulfillment. In this study, some professors have considered how these findings may affect them the same course suggested higher education program and related activities for instructing purposes and potential uses. Normally, we would say that proper education leads to effective knowledge as well as expected. It reaffirmed that teaching in the proper way and research can be an indispensable means to increase knowledge in the University for higher education. From this point of view, the professors' strengthened the have to motivate learners to innovate their exercise, whether it be looking for a place other than the classroom or finding standers methods of achieving knowledge. Moreover, this current study further considers that the teacher's approach to educational quality, such as the radical ideas of effective teacher teaching quality, is significant for improving the characteristics of efficiency.

As Martin Luther King mentions, "The profession of teaching is to instruct one to consider profoundly and to figure out critically" (Popil, 2011). This study emphasized effective teaching and learning strategy accomplishment in the classroom and laboratory by providing the students with an advance method to use their efficiency. In addition, encouraging instructors to accept potential way pedagogic into the classroom, practical, and use the laboratory to modify the concept of the material. It will help the teacher to represent the lessons in a more meaningful way, also favorable the educator to demonstrate the lesson in a more significant mode.

The study has been suggested that the method of discussion enhances students' ability to think critically and may further aid in intellectual growth, particular expression, and knowledge development. Advanced research requires a suitable environment, funding opportunities, and infrastructural development. The amount and quality of student interconnection should be the focus of the teacher. Specifically, the study's findings also suggest observations of higher education institutions commonly, their teaching practices that inspire the department to approach effectively and interfere when requiring better education to an essential. Further research may suggest scattering these and practices that help teachers and students become more effective and accepting approach the higher education. Therefore, the study may conduct in obsession programs desired at enhancing those who have to into the profession of instructing through substitute pathways rather than teacher knowledge of documentation.

Finally, this article may help to understand how new students bringing programs are prospective in university placing, how lessons are practice, and how educators involved in other research can have several prospects and methods of treating students.

\section{Limitations}

There are limitations to the study; the literature review study is based on a limited accumulation of very specific studies in the field regarding the selected topic. The factors are not conducted into this study framework, for example, every level of student's education teaching methods. In addition, the study is only playing a significant in the University Students and teachers. Therefore, the conclusions turn in from the former study which may not play role in innovative research in these factors.

\section{Acknowledgements}

We would like to thank the university professors and students who contributed to during collection of data in this study. Moreover, special thanks to Tory for countless support and pleasure discussion.

\section{References}

Abdulbaki, K., Suhaimi, M., Alsaqqaf, A., \& Jawad, W. (2018). The Use of the Discussion Method at University: Enhancement of Teaching and Learning. International Journal of Higher Educatio. https://doi.org/10.5430/ijhe.v7n6p118

Adams, D. J. (2009). Current Trends in Laboratory Class Teaching inUniversity Bioscience Programmes. Bioscience Education, 1-14. https://doi.org/10.3108/beej.13.3

Ali, A., Tariq, R. H., \& Topping, J. (2009). Students' perception of university teaching behaviours. Teaching in Higher 
Education, 631-647. https://doi.org/10.1080/13562510903315159

Allan, J., Clarke, K., \& Jopling, M. (2009). Effective Teaching in Higher Education: Perceptions of First Year Undergraduate Students. International Journal of Teaching and Learning in Higher Education, 362-372.

Behar-Horenstein, L. S., \& Niu, L. (2011). Teaching Critical Thinking Skills In Higher Education: A Review Of The Literature. Journal of College Teaching \& Learning. https://doi.org/10.19030/tlc.v8i2.3554

Bemowski, K. (1991). Restoring the pillars of higher education. Quality Progress, 37-42.

Berliner, D. (1983). The Executive Functions of Teaching. Instructo, 29-40.

Bidabadi, N. S., Isfahani, A. N., Rouhollahi, A., \& Khalili, R. (2016). Effective teaching methods in higher education: requirements and barriers. Journal of Advances in Medical Education \& Professionalism, 170-178.

Blatchford, P., Galton, M., Kutnick, P., \& Baines, E. (1995). Improving the Effectiveness of Pupil Groups in Classrooms. www.leeds.ac.uk, REFERENCE No. L139 251046.

Brew, A. (2006). Research and teaching: Changing relationships in a changing context. Studies in Higher Education, 291-301. https://doi.org/10.1080/03075079912331379905

Brew, A. (2010). Teaching and Research: New relationships and their implications for inquiry-based teaching and learning in higher education. Higher Education Research \& Development, 3-18. https://doi.org/10.1080/0729436032000056571

Bruce, C. S. (2013). Information literacy: a framework for higher. The Australian Library Journal, $158-170$. https://doi.org/10.1080/00049670.1995.10755718

Camacho, M. H., Valcke, M., \& Chiluiza, K. (2017). RESEARCH BASED LEARNING IN HIGHER EDUCATION: A REVIEW OF LITERATURE. 11th International Technology, Education and Development Conference (pp. 4188-4197. The International Academy of Technology. https://doi.org/10.21125/inted.2017.1004)

Chamorro-Premuzic, T., Furnham, A., \& Lewis, M. (2007). Personality and approaches to learning predict preference fordifferent teaching methods. Learning and Individual Differences, 241-250. https://doi.org/10.1016/j.lindif.2006.12.001

Diery, A., Seidel, T., Knogler, M., \& Vogel, F. (2020). Evidence-Based Practice in Higher Education: Teacher Educators' Attitudes, Challenges, and Uses. Teacher Education. https://doi.org/10.3389/feduc.2020.00062

Fullerton, A., \& Leckie, G. J. (1999). Information Literacy in Science and Engineering Undergraduate Education: Faculty Attitudes and Pedagogical Practices. College \& Research Libraries.

Gilmore, J., Lewis, D. M., Maher, M., Feldon, D., \& Timmerman, B. E. (2015). Feeding Two Birds with One Scone? The Relationship between Teaching and Research for Graduate Students across the Disciplines. International Journal of Teaching and Learning in Higher Education, 25-41.

Granjeiro, É. M. (2019). Research-based teaching-learning method: a strategy to motivate and engagestudents in human physiology classes. Advances in Physiology Education, 553-556. https://doi.org/10.1152/advan.00034.2019

Harvey, C., Bertolo, E., \& Byrne, L. (2017). Integrating Research and Knowledge Exchange in the Science Undergraduate Curriculum: Embedding Employability Through Research-Involved Teaching. IntechOpen, Global Voices in Higher Education. https://doi.org/10.5772/intechopen.68511

Hattwig, D., Bussert, K., Medaille, A., \& Joanna, B. (2013). Visual Literacy Standards in Higher Education: New Opportunities for Libraries and Student Learning. Libraries and the Academy, 61-89. https://doi.org/10.1353/pla.2013.0008

Hofstein, A., \& Lunetta, V. N. (1982). The Role of the Laboratory in Science Teaching: Neglected Aspects of Research. Review of Educational Research, 201-217. https://doi.org/10.3102/00346543052002201

Huisman, W., \& Kirschner, P. (2007). 'Dry laboratories' in science education; computer-based practical work. International Journal of Science Education, 665-682. https://doi.org/10.1080/0950069980200605

Jacobs, C. (2007). Mainstreaming academic literacy teaching: Implications for how academic development understands its work in higher education. South African Journal of Higher Education. https://doi.org/10.4314/sajhe.v21i7.25748

Jaffer, S., Ng'ambi, D., \& Czerniewicz, L. (2007). The role of ICTs in higher education in South Africa: One strategy 
for addressing teaching and learning challenges. International Journal of Education and Development using Information and Communication Technology, 131-142.

Kalyani, D., \& Rajasekaran, K. (2018). Innovative teaching andlearning. Journal of Applied and Advanced Research, S23-S25. https://doi.org/10.21839/jaar.2018.v3iS1.162

Khandelwal, K. A. (2009). Effective Teaching Behaviors in the College Classroom: A Critical Incident Technique from Students' Perspective. International Journal of Teaching and Learning in Higher Educatio, 299-309.

Kirschner, P. A., \& Meester, M. A. (1988). The laboratory in higher science education: Problems, premises and objectives. Higher Education, 81-98. https://doi.org/10.1007/BF00130901

Kugel, P. (1993). How Professors Develop as Teachers. Studies in Higher Education. https://doi.org/10.1080/03075079312331382241

Li, W. (2006). Sociocultural Learning Theories and Information Literacy Teaching Activities in Higher Education. Reference \& User Services Quarterly, 149-158. https://doi.org/10.5860/rusq.47n2.149

Livingston, K., McCall, J., \& Morgado, M. (2009). Teacher Educators as Researchers. Netherlands: Becoming a Teacher Educator, 191-203. https://doi.org/10.1007/978-1-4020-8874-214

Loughran, J. (2014). Professionally Developing as a Teacher Educator. Journal of Teacher Education, 271-283. https://doi.org/10.1177/0022487114533386

Marsh, H. W., \& Hattie, J. (2002). The Relation between Research Productivity and Teaching Effectiveness. The Journal of Higher Education, 603-641. https://doi.org/10.1080/00221546.2002.11777170

Marsh, H. W., \& Hattie, J. (2002). The Relation Between ResearchProductivity and Teaching Effectiveness. The Journal of Higher Education. https://doi.org/10.1353/jhe.2002.0047

McGuinness, C. (2006). What Faculty Think-Exploring the Barriers toInformation Literacy Development inUndergraduate Education. The Journal of Academic Librarianshi, 573-582. https://doi.org/10.1016/j.acalib.2006.06.002

Muhtasib, A. A. (2019). The Effect of Interactive Drills Using Dry Lab on the Acquisition of Laboratory Skills in Learning Science Among the Ninth-Grade Female Students in Palestine in Light of Their Thinking Style. Journal of Education and Learning. https://doi.org/10.5539/jel.v8n5p89

Murphy, L., Eduljee, N. B., Parkman, S., \& Croteau, K. (2018). Gender Differences in Teaching and Classroom Participation Methods: A Pilot Study. Journal of Psychosocial Research, 307-319. https://doi.org/10.32381/JPR.2018.13.02.5

Neumann, R. (1992). Perceptions of the teaching-research nexus: A framework for analysis. Higher Education, 159-171. https://doi.org/10.1007/BF00143643

Obwegeser, N., \& Papadopoulos, P. M. (2016). Integrating Research and Teaching in the IS Classroom: Benefits for Teachers and Students. Journal of Information Systems Education.

Perumal, D. (2009). Motivation Theories and Implications for Teaching and Learning in the Biosciences. Investigations in university teaching and learning.

Peter, C., \& Lawrence, S. (1999). Academic work in the twenty-first century: changing roles and policies. Australian Higher Education Division, Department of Education, Training and Youth Affairs.

Popil, I. (2011). Promotion of critical thinking by using case studies as teaching method. Nurse Education Today, 204-207. https://doi.org/10.1016/j.nedt.2010.06.002

Prince, M. J., Felder, R. M., \& Brent, R. (2007). Does Faculty Research Improve Undergraduate Teaching? An Analysis of Existing and Potential Synergies. Journal of Engineering Education. https://doi.org/10.1002/j.2168-9830.2007.tb00939.x

Regmi, K. (2012). A Review of Teaching Methods -Lecturing and Facilitation in Higher Education (HE): A Summary of the Published Evidence. The Journal of Effective Teaching, 61-76.

Sacchanand, C. (2002). Information literacy instruction to distance students in higher education: librarians' key role. (p. 268th IFLA Council and General Conference). http://www.ifla.org

Sikder, M., Xuecheng, D., \& Davi, L. (2020). Enlightment of Global advancement for future: One Belt One Road. International Journal of Economics and Finance, 12(6), 80-89. http://doi.org/10.5539/ijef.v12n6p80 
Suarman. (2015). Teaching Quality and Students Satisfaction: The Intermediatory Role of Relationship between Lecturers and Students of the Higher Learning Institutes. Mediterranean Journal of Social Sciences. https://doi.org/10.5901/mjss.2015.v6n2p626

Verburgh, A., Elen, J., \& Lindblom-Yla n̈ne, S. (2007). Investigating the myth of the relationship betweenteaching and research in higher education: A review of empirical research. Stud Philos Educ, 449-465. https://doi.org/10.1007/s11217-007-9055-1

Vries, Y. D., \& Beijaard, D. (1999). Teachers' Conceptions of Education: A Practical Knowledge Perspective on 'Good' Teaching. Interchange volume, 371-397. https://doi.org/10.1023/A:1007653627203

West, A., \& Bloxham, S. (2007). Learning to write in higher education: students' perceptions of an intervention in developing understanding of assessment criteria. Teaching in Higher Education, 77-89. https://doi.org/10.1080/13562510601102180

Wilson, A., Howitt, S., \& Wilson, K. (2012). Academics' perceptions of the purpose of undergraduate research experiences in a research-intensive degree. Studies in Higher Education, 513-526. https://doi.org/10.1080/03075079.2010.527933

Yakovleva, N. O., \& Yakovlevb, E. V. (2014). Interactive teaching methods in contemporary higher education. Pacific science review, 75-80. https://doi.org/10.1016/j.pscr.2014.08.016

Zemel, P. C., \& Groves, M. M. (2000). Instructional technology adoption in higher education: An action research case study. International Journal of Instructional Media, 57-65.

\section{Copyrights}

Copyright for this article is retained by the author(s), with first publication rights granted to the journal.

This is an open-access article distributed under the terms and conditions of the Creative Commons Attribution license (http://creativecommons.org/licenses/by/4.0/). 